\title{
IMPLEMENTASI LIFE CYCLE COST PADA GEDUNG BANK MANDIRI SYARIAH YOGYAKARTA
}

\author{
Sola Fide KRISNANDA \\ Jurusan Teknik Sipil, Fakultas Teknik, Universitas Atma Jaya Yogyakarta, D.I. Yogyakarta, Indonesia \\ *Email korespondensi: solafidekrisnanda98@gmail.com \\ [diterima: 20 April 2020, disetujui: 16 Juni 2020]
}

\begin{abstract}
In the building construction, the owner should be faced with various alternatives in choosing materials, products, or building systems. In addition to technical aspects, cost also becomes an important aspect that needs to be considered. The sustainable concept in the construction industry in Indonesia was initiated by the Green Building Council of Indonesia (GBCI) since 2008. GBCI works closely with the International Finance Corporation and the World Bank Groups to raise green building assessments. The application of life cycle cost to financial planning is in line with the concept of sustainability, which is a development that pays attention to the environment. Calculation methods are needed to find a more economical alternative, one of which is life cycle cost (LCC) analysis method. LCC calculates all costs start with initial costs, replacement, and operational costs and maintenance costs. The method used in this study is life cycle cost analysis based on ISO 15686: 5 with a period of 25 years. The net present value is also applied in calculations to find the current value of the total LCC. The results of calculations on the Bank Mandiri Syariah Yogyakarta building are formulated into three groups of cost estimates, namely initial costs, operational costs, and maintenance and replacement costs. The amount of these costs are Rp.19,412,002,758 (47\%), Rp.15,979,434,435 (39\%), and Rp.5,868,499,911 (14\%). The total LCC for 25 years is Rp.41,259,937,014.
\end{abstract}

Key words: Sustainable, life cycle cost, ISO 15686:5, net present value.

\section{INTISARI}

Dalam pembangunan sebuah gedung, pemilik gedung pasti dihadapkan dengan berbagai alternatif dalam melakukan pemilihan suatu material, produk attaupun suatu sistem gedung. Selain aspek teknis, biaya pun turut menjadi aspek penting yang perlu menjadi salah satu pertimbangan. Konsep sustainable pada industri konstruksi di Indonesia diprakarsai oleh Green Building Council of Indonesia (GBCI) sejak tahun 2008. GBCI bekerja sama dengan International Finance Corporation dan World Bank Groups mengangkat asesmen green building. Diterapkannya life cycle cost pada perencanaan pembiayaan, sudah sejalan dengan konsep sustainability, yaitu pembangunan yang memperhatikan lingkungan. Untuk mengetahui pilihan alternatif yang lebih hemat, diperlukan metode penghitungan, salah satunya adalah dengan menggunakan metode analisis life cycle cost (LCC). LCC menghitung keseluruhan biaya mulai dari biaya awal, biaya penggantian serta biaya operasional dan pemeliharaan. Metode yang dilakukan pada studi ini menggunakan life cycle cost analysis berdasarkan ISO 15686:5 dengan periode 25 tahun. Net present value juga diterapkan dalam perhitungan untuk mencari nilai saat ini dari total LCC. Hasil perhitungan pada bangunan Bank Mandiri Syariah Yogyakarta dirumuskan menjadi tiga kelompok estimasi biaya yaitu biaya awal, biaya operasional dan biaya pemeliharan dan penggantian. Besar biaya tersebut masing-masing Rp 19,412,002,758 (47\%), Rp 15,979,434,435 (39\%) dan Rp 5,868,499,911 (14\%). Total LCC 25 tahun sebesar Rp 41,259,937,014.

Kata kunci: Sustainable, life cycle cost, ISO 15686:5, net present value. 


\section{PENDAHULUAN}

Tahapan-tahapan pada proyek konstruksi biasanya saling terkait dan berjalan dengan jelas atau sering disebut siklus proyek konstruksi. Negara-negara berkembang seperti Indonesia umumnya masih lemah pada tahapan operasi dan pemeliharaan. Ketika membuat bangunan atau infrastuktur baru, kebanyakan pengelola proyek tidak mempertimbangkan fasilitas pengoperasian dan pemeliharaan. Penyebab terjadinya hal tersebut adalah kurangnya pengetahuan life cycle cost, selain juga ketersediaan dana yang terbatas. Padahal hal tersebut menjadi sangat penting untuk mencapai usia layanan suatu bangunan/ infrastuktur. Life cycle cost merupakan total biaya yang dikeluarkan sepanjang siklus hidup suatu sistem yang langsung berhubungan dengan biaya kepemilikan selama umur ekonomis.

Konsep sustainable pada industri konstruksi di Indonesia diprakarsai oleh Green Building Council of Indonesia (GBCI) sejak tahun 2008. GBCI bekerja sama dengan International Finance Corporation dan World Bank Groups mengangkat asesmen green building. Diterapkannya life cycle cost pada perencanaan pembiayaan, sudah sejalan dengan konsep sustainability, yaitu pembangunan yang memperhatikan lingkungan. Estimasi proses pembangunan berdasarkan life cycle cost telah mengintegrasikan pengambilan keputusan, perencanaan, pengadaan, operasional, keamanan dan nilai final suatu proyek. Hal tersebut merupakan konsep yang sejalan dengan konstruksi berkelanjutan.

Bedasarkan situasi tersebut, maka metode life cycle cost (LCC) menjadi salah satu faktor penting dalam pengelolaan proyek konstruksi karena metode ini dapat mengestimasi biaya pemeliharaan dan penggantian secara berkala pada tiap komponen bangunan dalam periode waktu tertentu. Perhitungan LCC didasarkan pada ISO 15686:5 dan metode net present value (NPV).

\section{PENGERTIAN LCC}

LCC merupakan suatu gagasan yang menjelaskan bahwa semua biaya akan timbul akibat keputusan investasi tersebut. LCC merupakan langkah maju untuk mengendalikan biaya konstruksi. Rencana LCC merupakan perhitungan semua biaya aktual dan pendapatan yang terkait dengan aset-aset tertentu sepanjang usia layan. Semua informasi seperti jumlah dan jenis biaya dalam periode tertentu untuk investasi, dianalisis melalui perencanaan LCC.

Ada beberapa pengertian LCC menurut beberapa ahli, diantaranya sebagai berikut:

1. Sawant, Atpadkar dan Kognole (2018), LCC yaitu total biaya kepemilikan, pengoperasioan, pemeliharaan dan nilai sisa dari sebuah bangunan atau sistem bangunan.

2. Zabielski and Zabielska (2018) merumuskan LCC sebagai jumlah dari biaya pembelian (biaya pelaksanaan proyek), biaya kepemilikan (pemeliharaan) dan nilai sisa suatu properti.

3. Heralova (2017) berpendapat bahwa LCC adalah metode analisis ekonomi dari semua biaya yang terkait dengan pembangunan, pengoperasian, dan pemeliharaan proyek konstruksi selama periode waktu tertentu. Optimalisasi LCC proyek, konstruksi atau peralatan, sangat penting untuk proses pengambilan keputusan yang kompleks.

4. Menurut Devi dan Priyanth (2016), Analisis LCC merupakan metode untuk menghitung biaya jangka pendek maupun biaya jangka panjang yang meliputi biaya pengadaan material, konstruksi, manajemen, instalasi, operasional, pemeliharaan, perbaikan, rehabilitasi dan penggantian serta penghancuran.

5. Rashid (2016), mendefinisikan LCC sebagai total diskon biaya kepemilikan suatu bangunan sepanjang usia layan. 
6. Kovacic dan Zoller (2015) LCC pada umumnya terdiri dari investasi awal (biaya konstruksi) dan biaya tindak lanjut (pembayaran energi, utilitas, pembersihan dan pemeliharaan, biaya tak tentu untuk pembaruan atau penggantian), beberapa metode LCC juga mencakup biaya pembongkaran.

LCC dapat dirumuskan seperti persamaan di bawah ini:

\section{$L C C=$ Biaya Awal + Operasional + Biaya Pemeliharaan dan Penggantian}

\section{NET PRESENT VALUE}

Spickova dan Myskova (2015), Net Present Value adalah alat dasar untuk mebandingkan nilai uang di waktu yang berbeda. Kesulitan akan muncul ketika ingin mengevaluasi faktor diskon tertentu. Dalam perhitungan keuangan ini sangat berkaitan dengan tingkat bebas risiko dan premi ekuitas, yang menurut teori modern diturunkan dengan kovarians dari hasil dan konsumsi saham ekuitas tertentu.

Heralova (2014), Metode arus kas yang didiskontokan sering digunakan untuk perhitungan biaya siklus hidup (LCC). Pendekatan yang paling cocok dan paling umum digunakan dalam menilai biaya siklus hidup bangunan adalah Net Present Value (NPV) dan Equivalent Annual Cost (EAC).

\section{PENERAPAN LCC}

Peneletian sejenis yang dilakukan sebelumnya diharapkan akan menjadi bahan pertimbangan dan referensi untuk penelitian yang sedang dilakukan. Hasil penelitian yang terkait dengan penelitian ini yaitu:

1. Das dkk. (2015), Penelitian dilakukan di Hazrat Shahjalal International Airport yang bertujuan merencanakan biaya pekerjaan perkerasan runway menggunakan pendekatan LCC dengan periode analisis 20 tahun untuk memilih perkerasan dengan biaya paling efektif.
Hasil penelitian ini adalah total biaya perkerasan kaku pada akhir usia layan lebih efektif dari pada perkerasan lentur. Dalam hal ini, penggunaan perkerasan kaku akan menghemat biaya sekitar empat persen. Rincian biaya perkerasan kaku yaitu biaya pembuatan awal sebesar USD 22,844,406.40 dan biaya M\&R sebesar USD 1,385,610.05, sedangkan rincian biaya perkerasan lentur yaitu biaya pembuatan awal sebesar USD $18,931,110.85$ dan biaya $M \& R$ sebesar USD 6,372,943.33.

2. Sawant, Atpadkar dan Kognole (2018), menungkapkan bahwa perencanaan bangunan tempat tinggal hanya mempertimbangkan biaya awal, tanpa mempertimbangkan biaya operasional dan pemeliharaanyang terjadi selama umur bangunan. Berdasarkan latar belakang tersebut penelitian ini bertujuan untuk menerapakan metode LCC pada pembangunan bungalo. Analisis LCC ini dilakukan dengan mempertimbangkan discount rate $6.25 \%$, inflation rate $5.52 \%$ dan periode 50 tahun. Hasil dari penelitian ini yaitu biaya operasional dan pemeliharaan memiliki presentase paling tinggi sebesar $45 \%$. Biaya penggunaan energi berkontribusi paling besar pada biaya operasional dan pemeliharaan yaitu sebesar 56\%. Pada penelitian ini dihasilkan lima kelompok biaya yaitu biaya akuisis tanah sebesar Rs.7,500,000, biaya konstruksi Rs.1,557,721.69, biaya pemeliharaan sebesar Rs.758,601.57. biaya operasional sebesar Rs.1,111,485.80 dan nilai sisa bangunan sebesar Rs.86963.98.

3. Rasane dan Ambre (2019), Penelitian ini dilakukan untuk mengetahui analisis LCC pada infrastruktur jalan dengan periode 10 tahun. Objek dari penelitian yaitu jalan raya Ghoti- Sinnar-Nagpur, Maharashtra, India dengan panjang $26 \mathrm{~km}$. Penelitian ini menghasilkan tiga kelompok biaya 
yaitu biaya konstruksi Rs 260,753,940, biaya operasional dan pemliharaan sebesar Rs.129,128,450.38 dan nilai sisa infrastruktur sebesar Rs.2,675,394.

Penelitian ini dilakukan oleh Heralova (2017) di dua tempat yaitu Supreme Audit Office (SAO) Republik Ceko dan Depository building for Náprstek Museum of Asian, African and American Cultures di Republik Ceko. Pada tempat pertama dilakukan analisis LCC dan dihasilkan total biaya sebesar 19,640,000 EUR dengan lima kategori biaya yaitu biaya konstruksi 21,050,000 EUR, biaya sewa $1,860,000$ EUR, biaya operasional $8,140,000$ EUR, biaya pemeliharaan 3,590,000 EUR dan nilai sisa diestimasikan sebesar 15,000,000 EUR. Pada bangunan kedua dilakukan perhitungan LCC dengan periode 20 tahun dan dihasilkan biaya total 5,790,000 EUR dengan tiga kategori biaya yaitu biaya konstruksi 3,240,000 EUR, biaya operasional 1,900,000 EUR dan biaya pemeliharaan 650,000 EUR.

\section{METODE PENELITIAN}

\section{Objek Penelitian}

Bank Syariah Mandiri Yogyakarta berlokasi di Jl. Jenderal Sudirman No.42, Terban, Gondokusuman, DIY. Gedung ini memiliki empat lantai dan satu basement dengan estimasi luas basement $760 \mathrm{~m} 2$, lantai 1, 2 dan 3 masing-masing sebesar $655 \mathrm{~m} 2$ serta lantai 4 seluas $445 \mathrm{~m} 2$ sehingga luas total lantai sebesar $3170 \mathrm{~m} 2$. Bangunan ini dibangun pada tahun 2017 dan berdiri di tanah seluas $1180 \mathrm{~m} 2$. Biaya konstruksi dihitung ulang menggunakan harga satuan tahun 2019. Gedung ini akan diestimasi menggunakan metode LCC dengan periode siklus hidup 25 tahun.

\section{Metode Pengumpulan Data}

Data yang dikumpulkan pada penelitian kali ini berupa shop drawing sebagai acuan pelaksanaan pekerjaan Bank Syariah Mandiri
Yogyakarta, tabel harga satuan pekerjaan, rencana anggaran biaya (RAB) dan data-data lain yang diperlukan dari pihak terkait. Selain itu dilakukan studi literatur untuk mendapatkan data standar umur hidup komponen material proyek.

\section{Metode Analisis Data}

Berdasarkan tujuan dari penelitian, metode analisis yang dilakukan dalam menghitung biaya LCC Gedung Bank Syariah Mandiri, tahapan analisis data dinyatakan sebagai berikut:

1. Melakukan perhitungan biaya awal investasi yang terdiri dari biaya konstruksi, biaya pengadaan tanah, biaya perencanaan, biaya pengawasan;

2. Melakukan perhitungan biaya operasional yang terdiri dari gaji pegawai, estimasi biaya energi (listrik dan air);

3. Menghitung biaya pemeliharaan;

4. Menghitung biaya penggantian.

Melakukan konversi biaya total ke nilai sekarang menggunakan metode NPV.

\section{Model Biaya LCC}

Rencana LCC merupakan suatu rencana mengenai pengeluaran usulan dari suatu proyek konstruksi sepanjang usia proyek tersebut. Pada pelaksanaan pembangunan, mulai dari ide, studi kelayakan, perencanaan, pelaksanaan, sampai pada operasi pemeliharaan dibutuhkan bermacam-macam biaya yang dikelompokkan menjadi beberapa komponen yaitu:

\section{Biaya Awal}

Biaya awal adalah jumlah semua pengeluaran yang dibutuhkan mulai dari pra studi hingga proyek selesai dibangun, mulai dari biaya persiapan, biaya perencanaan, biaya konstruksi dan pengawasan.

2. Biaya Operasional

Biaya operasional adalah biaya yang dikeluarkan oleh pengelola untuk 
menjalankan tugas sehari-hari. Biaya ini meliputi gaji pegawai, biaya listrik, biaya fasilitas umum dan lain-lain.

3. Biaya Pemeliharaan dan Penggantian

Rencana biaya pemeliharaan dan penggantian merupakan kegiatan yang sering tidak diperhitungkan dalam jangka waktu panjang pada pengelolaan suatu konstruksi. Biaya ini meliputi semua biaya penggantian, pemeliharaan dan adaptasi aset yang dibangun.

\section{HASIL DAN DISKUSI}

\section{Analsis Data}

Usia layan dan item yang memerlukan penggantian diperoleh melalui kajian pustaka dari penelitian serupa. Data usia layanan komponen material dapat dilihat seperti Tabel 1.

\section{Perhitungan LCC}

Biaya Awal Konstruksi

Biaya awal terdiri dari biaya prakonstruksi, biaya konstruksi dan biaya pengawasan. Perhitungan masing-masing tahap pekerjaan diuarikan sebagai berikut:

1. Biaya Pra Konstruksi

Dalam Peraturan Daerah Kota Yogyakarta No. 25 Tahun 2009, biaya retribusi untuk pembangunan Gedung dihitung $1.75 \%$ dari harga total konstruksi. Biaya perizinan didapat sebesar Rp.323,922,007.50.

Biaya upaya pengelolaan lingkungan hidup dan upaya pemantauan lingkunagn hidup menurut Peraturan Bupati Sleman Nomor 44 Tahun 2016 tentang standar harga barang dan jasa menerangkan bahwa biaya UPL/UKL adalah Rp.10,000,000/ha. Proyek ini memiliki biaya sebesar Rp.10,000,000.

Menurut Peraturan Bupati Sleman Nomor 44 Tahun 2016 Tentang Standar Barang dan Jasa ditetapkan biaya perencanaan sebesar $1,84 \%$ dari nilai total proyek. Total biaya yang diperoleh sebesar Rp.340,580,853.60.

Tabel 1. Umur Layan Komponen Bangunan

\begin{tabular}{|c|c|c|}
\hline Item & Komponen Bangunan & $\begin{array}{l}\text { Umur } \\
\text { Layan } \\
\text { (tahun) }\end{array}$ \\
\hline \multirow[t]{3}{*}{ Atap } & Streel Roof Frame & 30 \\
\hline & Roof Clay Tile & 20 \\
\hline & Gutter & 15 \\
\hline \multirow[t]{9}{*}{ Dinding } & Wall Paint & 8 \\
\hline & Aluminium Paint & 12 \\
\hline & Wood Paint & 15 \\
\hline & Frame Aluminium & 15 \\
\hline & Door Aluminium & 15 \\
\hline & Timber Frame & 30 \\
\hline & Timber Door & 30 \\
\hline & Timber Window & 30 \\
\hline & $\begin{array}{l}\text { Door and Window } \\
\text { Glass }\end{array}$ & 20 \\
\hline \multirow[t]{2}{*}{ Lantai } & Granit & 20 \\
\hline & Ceramic & 20 \\
\hline \multirow{2}{*}{ Plafon } & Gypsum & 15 \\
\hline & $G R C$ & 18 \\
\hline \multirow[t]{7}{*}{ Sanitasi } & Wastafel & 8 \\
\hline & Stainless Steel Sink & 12 \\
\hline & Water Crane & 3 \\
\hline & Water Closet & 15 \\
\hline & Shower & 8 \\
\hline & Floor Drain & 8 \\
\hline & $P V C$ pipe & 30 \\
\hline \multirow[t]{3}{*}{ Asesori } & Slot Door \& Window & 10 \\
\hline & HandleDoor\& Window & 10 \\
\hline & Hinge Door \& Window & 20 \\
\hline \multirow[t]{12}{*}{ ME } & Lamp Standart & 5 \\
\hline & Lamp Down Light & 5 \\
\hline & Wall Stop Contact & 20 \\
\hline & Saclar Single & 20 \\
\hline & Saclar Multiple & 20 \\
\hline & Fitting & 20 \\
\hline & Lift & 30 \\
\hline & Fire Alaram & 30 \\
\hline & Telephon & 15 \\
\hline & $C C T V$ & 30 \\
\hline & Water Heater & 15 \\
\hline & $A C$ & 15 \\
\hline
\end{tabular}

(Sumber: Kaming dan Marliansyah, 2015) 
2. Biaya Konstruksi Awal

Data biaya konstruksi awal diperoleh dari pihak konsultan pada tahun 2017. Dalam kasus ini dilakukan perhitungan ulang menggunakan analisis harga satuan kota Yogyakarta tahun 2019. Biaya yang dihitung meliputi semua biaya kosntruksi, mulai dari pekerjaan persiapan hingga finishing. Hasil perhitungan biaya konstruksi awal dapat dilihat pada Tabel 2.

Tabel 2. Biaya Konstruksi Awal

\begin{tabular}{|c|c|c|c|}
\hline No & Uraian Pekerjaan & Proporsi (\%) & Total Biaya \\
\hline I & P. Persiapan & 1.35 & Rp 223,620,878 \\
\hline II & P.Tanah dan Pondasi & 10.34 & $\operatorname{Rp} 1,708,692,873$ \\
\hline III & P. Struktur & 38.93 & $\operatorname{Rp} 6,433,452,082$ \\
\hline IV & P. Atap & 16.53 & $\operatorname{Rp} 2,731,394,473$ \\
\hline V & P. Pasangan & 5.50 & Rp 908,576,239 \\
\hline VI & P. Waterproofing & 2.97 & $\operatorname{Rp} 491,621,148$ \\
\hline VIII & P. Logam & 0.08 & Rp 13,120,869 \\
\hline VIII & P.Pintu dan Jendela & 1.42 & Rp 235,315,674 \\
\hline VIII & P. Sanitasi & 0.30 & Rp 50,034,085 \\
\hline IX & P. Plafond dan Partisi & 2.64 & $\operatorname{Rp} 435,759,413$ \\
\hline $\mathbf{X}$ & P. Finishing & 10.78 & Rp 1,780,919,496 \\
\hline XI & P. Instalasi Penerangan & 4.29 & Rp 708,685,680 \\
\hline XII & P. Instalasi Data LAN & 0.25 & $\operatorname{Rp} 41,320,920$ \\
\hline XIII & P. Instalasi Fire Alarm & 0.63 & Rp 104,708,750 \\
\hline XIV & P. Instalasi Tray Kabel & 0.25 & $\operatorname{Rp} 41,245,112$ \\
\hline $\mathbf{X V}$ & P.Instalasi Telepon & 0.03 & Rp 4,686,662 \\
\hline XVI & P. Instalasi Air Bersih & 0.03 & Rp 5,545,460 \\
\hline XVII & P. Instalasi Air Bekas dan Kotor & 0.09 & Rp $14,882,718$ \\
\hline XVIII & P. Hydrant Sprinkler & 0.69 & Rp 114,813,296 \\
\hline XIX & P. Instalasi Lift & 2.33 & Rp 385,889,500 \\
\hline \multirow[t]{5}{*}{$\mathbf{X X}$} & P. Lain-lain & 0.56 & Rp 92,348,320 \\
\hline & Total & 100 & Rp 16,526,633,650 \\
\hline & & Overhead $1-3 \%$ & Rp 330,532,673 \\
\hline & & PPH $10 \%$ & $\operatorname{Rp} 1,652,663,365$ \\
\hline & & Grand Total & Rp $18,509,829,688$ \\
\hline
\end{tabular}

3. Biaya Pengawasan

Menurut Peraturan Bupati Sleman Nomor 44 Tahun 2016 Tentang Standar Barang dan Jasa ditetapkan biaya pengawasan $1,23 \%$ dari nilai total proyek. Biaya pengawasan diperoleh sebesar Rp.227,670,897. Rekaptiulasi biaya konstruksi, biaya pra-konstruksi dan biaya pengawasan dapat dilihat pada Tabel 3 dan Gambar 1.
Tabel 3. Rekapitulasi Biaya Awal

\begin{tabular}{clr}
\hline No & Kebutuhan & \multicolumn{1}{c}{ Jumlah } \\
\hline 1 & Pra Konstruksi & Rp 674,502,861 \\
2 & Konstruksi & Rp $18,509,829,000$ \\
3 & Pengawasan & Rp 227,670,897 \\
\hline
\end{tabular}




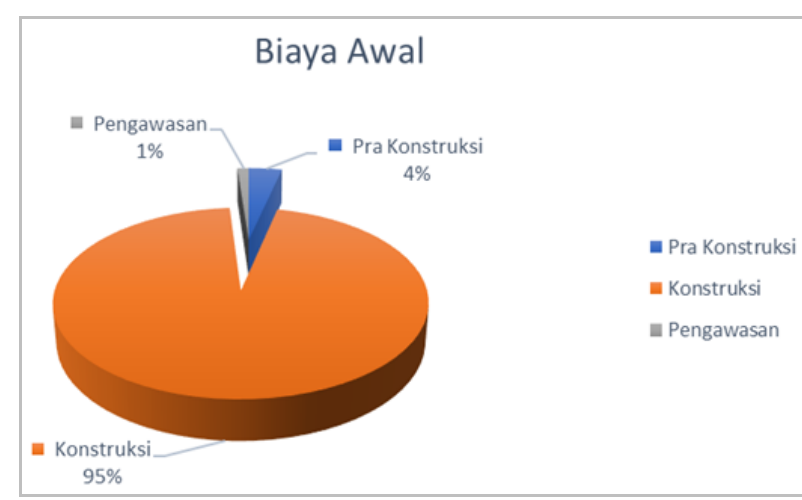

Gambar 1. Proporsi Biaya Awal

Berdasarkan analisis biaya awal, diketahui bahwa biaya konstruksi memiliki proporsi paling besar dengan presentase 95\%, diikuti oleh biaya pra-konstruksi dan biaya pengawasan dengan presentase masingmasing $4 \%$ dan $1 \%$.

\section{Biaya Operasional}

Biaya operasional merupakan biaya yang diutuhkan untuk menjamin bangunan menjalankan fungsinya dengan baik. Biaya opersional pada pembahasan ini meliputi gaji pegawai, tarif listrik dan air, biaya PBB (pajak bumi dan bangunan) dan biaya asuransi. Perhitungan biaya operasional dapat dilihat pada penjelasan di bawah, sebagai berikut:

\section{Gaji Pegawai}

Dalam melakukan kegiatan operasional, Bank Syariah Mandiri mempekerjakan pegawai sebanyak 19 orang yang meliputi 8 petugas administrasi, 3 satpam. 3 teknisi dan 5 petugas kebersihan. Gaji pegawai mengacu Peraturan Gubernur Daerah Istimewa Yogyakarta Nomor 40 Tahun 2018 tentang Standar Harga Barang dan Jasa Daerah. Gaji pegawai diasumsikan mengalami kenaikan setiap 5 tahun lalu disesuaikan dengan rata-rata inflasi sebesar $5 \%$.

\section{Kebutuhan Air}

Konsumsi rata-rata air tiap orang rata-rata sebanyak 144liter perhari (Ditjen Cipta Karya, 2006). Menurut Peraturan Walikota Daerah Istimewa Yogyakarta Nomor 93 Tahun 2019, tarif air bersih per m3 sebesar Rp.3,420. Kenaikan tarif air bersih diasumsikan naik setiap 5 tahun sekali dan dipengaruhi oleh inflasi sebesar $5 \%$.

3. Kebutuhan Listrik

Daya listrik dihitung berdasarkan daya tiap peralatan yang digunakan dalam kegiatan operasional bangunan. Tarif listrik untuk perkantoran per $\mathrm{kWh}$ adalah Rp.1,115.

4. Pajak Bumi dan Bangunan

Besar tarif Pajak Bumi dan Bangunan (PBB) ditentukan berdasarkan luas bangunan (per m2). Pajak bumi memliki tarif sebesar Rp.1,180/m2, sedangkan tarif pajak bangunan sebesar Rp.3,170/m2. PBB terutang dihitung $0.2 \%$ dari total biaya PBB.

5. Biaya Asuransi

Peraturan Otoritas Jasa Keuangan (OJK) tahun 2015 tentang Penetapan Tarif untuk gedung atau apartemen dengan jumlah lantai di bawah 6 lantai dihitung sebesar $0.35 \%$ dari total harga bangunan.

Hasil rekapitulasi biaya operasional dan proporsi biaya dapat dilihat pada Tabel 4 dan Gambar 2 seperti di bawah ini:

Tabel 4. Biaya Operasional

\begin{tabular}{|c|c|c|}
\hline No & Kebutuhan & Jumlah \\
\hline 1 & Gaji Pegawai & $\operatorname{Rp} 14,531,036,835$ \\
\hline 2 & Kebutuhan Air & Rp 462,767,404 \\
\hline 3 & Kebutuhan Listrik & Rp 897,620,125 \\
\hline 4 & PBB & $\operatorname{Rp} 23,225,580$ \\
\hline 5 & Asuransi & $\operatorname{Rp} 64,784,402$ \\
\hline & Total & Rp $15,979,434,345$ \\
\hline
\end{tabular}

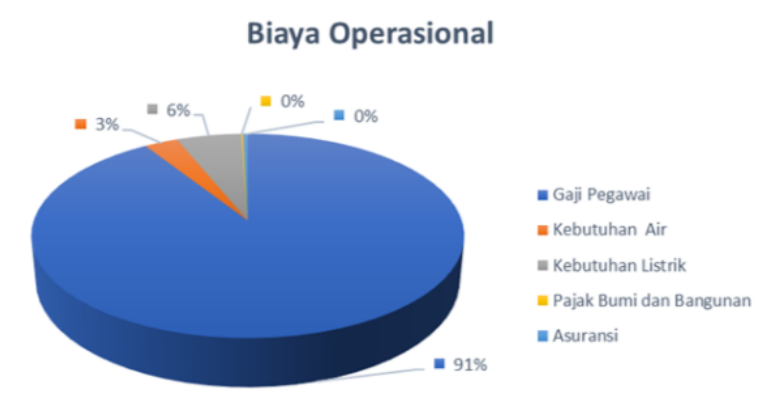

Gambar 2. Proporsi Biaya Operasional 
Dari Tabel 4 dan Gambar 2, dapat diketahui bahwa gaji pegawai memiliki kontribusi biaya paling signifikan terhadap biaya operasional dengan presentase $91 \%$ dan biaya sebesar Rp.14,531,036,835. Selanjutnya diikuti berturut-turut (dalam presentase) oleh kebutuhan listrik 5.62\%, kebutuhan air 2.9\%, asuransi $0.41 \%$ dan pajak bumi bangunan $0.15 \%$.

\section{Biaya Pemeliharaan dan Penggantian}

Perhitungan biaya pemeliharaan mengacu pada Peraturan Menteri Pekerjaan Umum Nomor 45 Tahun 2007. Biaya pemeliharaan dihitung $2 \%$ dari harga per $\mathrm{m} 2$ tertinggi yang berlaku, lalu dikalikan dengan luas lantai bangunan. Total biaya pemeliharaan didapat sebesar Rp.76,080,000, sedangkan biaya penggantian seperti di Tabel 5.

Tabel 5. Biaya Penggantian

\begin{tabular}{|c|c|c|c|}
\hline Pekerjaan & Item Pekerjaan & Kala Ulang & Total Biaya \\
\hline \multirow[t]{4}{*}{ Pengecatan } & Dinding & 3 & Rp 1,019,695,213 \\
\hline & Plafond & 3 & $\operatorname{Rp} 220,118,184$ \\
\hline & daun pintu dan jendela & 3 & Rp 19,965,806 \\
\hline & Railing tangga & 3 & Rp 11,526,929 \\
\hline \multirow[t]{5}{*}{ Komponen Pintu } & Daun pintu alumunium & 1 & $\operatorname{Rp} 93,750,000$ \\
\hline & Daun jendela aluminium & 1 & Rp 99,000,000 \\
\hline & Kunci tanam & 1 & $\operatorname{Rp} 5,250,000$ \\
\hline & Engsel pintu & 1 & $\operatorname{Rp} 12,162,500$ \\
\hline & Engsel jendela & 1 & $\operatorname{Rp} 7,395,000$ \\
\hline \multirow[t]{2}{*}{ Plafond } & Plafond Gypsum Board & 2 & $\operatorname{Rp} 746,650,000$ \\
\hline & Plafond Kalsi Board & 2 & Rp 338,086,667 \\
\hline Pekerjaan Atap & Atap zincalume & 1 & $\operatorname{Rp} 121,867,730$ \\
\hline \multirow[t]{6}{*}{ Pekerjaan Sanitair } & Closet & 2 & Rp $118,516,667$ \\
\hline & Shower Spray & 3 & $\operatorname{Rp} 8,632,813$ \\
\hline & Wastafel & 3 & $\operatorname{Rp} 55,687,500$ \\
\hline & Urinal & 2 & $\operatorname{Rp} 5,177,083$ \\
\hline & Kran Air Bersih & 8 & Rp 55,500,000 \\
\hline & Floor Drain & 3 & $\operatorname{Rp} 27,134,375$ \\
\hline \multirow[t]{6}{*}{ Pekerjaan MEP } & Keran air & 2 & $\operatorname{Rp} 2,250,000$ \\
\hline & Saklar tunggal & 1 & $\operatorname{Rp} 2,400,000$ \\
\hline & Saklar ganda & 1 & $\operatorname{Rp} 3,372,500$ \\
\hline & Stop kontak & 1 & $\operatorname{Rp} 9,375,000$ \\
\hline & Lampu & 8 & $\operatorname{Rp} 91,500,000$ \\
\hline & Telephon & 2 & Rp $10,500,000$ \\
\hline \multirow[t]{9}{*}{ Pekerjaan Lain-lain } & Railing tangga & 1 & $\operatorname{Rp} 8,402,342$ \\
\hline & & aya Penggantian & Rp 3,093,916,308 \\
\hline & & aya Pemasangan & Rp 92,817,489 \\
\hline & & rhead dan Profit & $\operatorname{Rp} 77,347,908$ \\
\hline & & Grand Total & Rp 3,264,081,705 \\
\hline & \multicolumn{3}{|c|}{ Discount Factor-3.5\% } \\
\hline & & Present Value & Rp 1,710,696,961 \\
\hline & & Inflasi-5\% & \\
\hline & Gra & LCC (25 tahun) & Rp 5,792,419,911 \\
\hline
\end{tabular}


Proporsi biaya penggantian secara khusus dijelaskan pada Gambar 3. Biaya penggantian mengacu pada estimasi jangka waktu 25 tahun terhitung dari tahun 2017 hingga 2042. Gedung mulai selesai dibangun tahun 2017. Perhitungan metode LCC pada tiap komponen pekerjaan dapat dilihat pada Tabel 5. Hasil analisis yang diperoleh dengan mempertimbangkan nilai inflasi 5 persen per tahun mencapai nilai sebesar Rp.5,792,419,911.

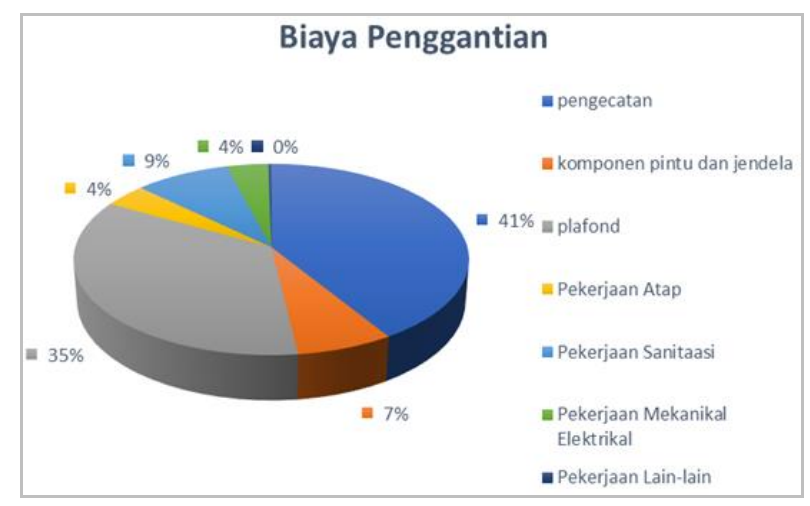

Gambar 3. Proporsi Biaya Penggantian

\section{Total Biaya LCC}

Hasil perhitungan menunjukan bahwa biaya awal memiliki proporsi biaya paling besar dengan nilai biaya sebesar Rp.19,412,002,758. Total biaya LCC 25 tahun untuk Bank Syariah Mandiri dapat dilihat pada Tabel 6 dan Gambar 4.

Tabel 6. Biaya LCC 25 Tahun

\begin{tabular}{clr}
\hline No & \multicolumn{1}{c}{ Kebutuhan } & \multicolumn{1}{c}{ Jumlah } \\
\hline 1 & Biaya Awal & $\operatorname{Rp~19,412,002,758}$ \\
2 & Biaya Operasional & $\operatorname{Rp~} 15,979,434,345$ \\
3 & Biaya M\&R & $\operatorname{Rp~5,868,499,911}$ \\
& Total & $\operatorname{Rp~41,259,837,014}$ \\
\hline
\end{tabular}

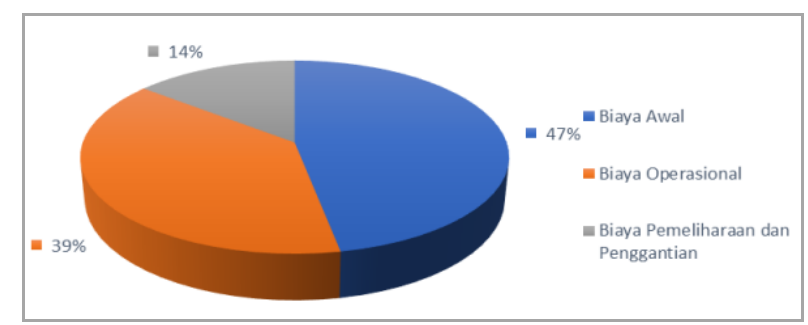

Gambar 4. Proporsi LCC 25 Tahun
Berdasarkan analisis yang dilakukan, Tabel 6 dan Gambar 4 menyatakan bahwa biaya awal memiliki presentase paling tinggi yaitu sebesar 47\% (Rp.19,412,002,758) diikuti oleh biaya operasional dan biaya pemeliharaan dan penggantian yang memiliki presentase masing-masing 39\% (Rp.15,979,434,345) dan 14\% (Rp.5,868,499,911).

\section{KESIMPULAN}

Perhitungan LCC berdasarkan ISO 15686:5 yang dilakukan pada bangunan Bank Mandiri Syariah Yogyakarta menghasilkan tiga kelompok estimasi biaya yaitu biaya awal, biaya operasional dan biaya pemeliharan dan penggantian dengan besar biaya masingmasing $\mathrm{Rp} 19,412,002,758 \quad(47 \%), \quad \mathrm{Rp}$ 15,979,434,435 (39\%) dan Rp 5,868,499,911 (14\%). Total LCC 25 tahun sebesar Rp $41,259,937,014$.

Studi ini memberikan beberapa rekomendasi seperti memberikan gambaran bagi investor dalam memperhatikan kinerja sistem bangunan selama umur layan gedung dalam pengambilan keputusan. Memberikan manfaat pada setiap stakeholder yang terlibat dalam proses konstruksi sehingga dapat mencipatakan kinerja yang terintegrasi. Penelitian selanjutnya perlu mengkaji lebih dalam mengenai usia layan tiap komponen bangunan supaya perhitungan dapat dilakukan secara lebih komprehensif dan tepat.

\section{UCAPAN TERIMA KASIH}

Terima kasih kepada konsultan yang telah menyiapkan data dan para ahli yang telah membuat literatur sebagai acuan untuk penelitian ini. Terima kasih kepada Bapak Peter F. Kaming, Ph.D. sebagai dosen Manajemen Konstruksi, Magister Teknik Sipil Universitas Atma Jaya Yogyakarta yang telah membimbing dalam studi ini. Terimakasih atas saran dari para reviewer jurnal. 


\section{REFERENSI}

Ambre, Rasane, 2019. A Study on Life Cycle Cost Analysis for Roads. International Research Journal of Engineering and Technology. 6 (5).

Atpadkar, Kogonole, Sawant, 2018. Cost Optimization of Residential Structure by Life Cycle Cost Analysis. International Journal of Trend in Scientific Research and Development. 2(2):1583-1586.

Building and Constructed Assets: Service Life Planning - Part 5: Life Cycle Costing. ISO 15686-5. 2008., ISO Geneva.

Devi, Priyanth, 2016. Comparison of Sea Bridge and Under Water Tunnel using Life Cycle Cost Analysis (LCCA). IJSART 2(9): 327-333.

Heralova, 2014. Life Cycle Cost Optimization within Decision Making on Alternative Designs of Public Buildings. Procedia Engineering. 85:454-463.
Heralova, 2017. Life Cycle Costing as an Important Contribution to Feasibility Study in Construction Projects. Procedia Engineering 196: 565 - 570.

Kovacic, I., Zoller, V., 2015. Building Life Cycle Optimization Tools for Early Design Phases. Energy, 92:409-419

Myskova, Spickova, 2015. Costs Efficiency Evaluation using Life Cycle Costing as Strategic Method. Procedia Economics and Finance. 34:337 - 343.

Rashid, 2016. Investigation on Reliability and Validity of Life Cycle Cost (LCC) Data Inputs of Building. IIUM. Malaysia: IIUM Press.

Zabielski, J., Zabielska, I., 2018. Life Cycle of a Building (LCC) in the Investment Process- Case Study. In Proceedings of the Baltic Geodetic Congress, BGCGeomatics, Olsztyn. Poland, 21-23. 